\title{
DISSOLVED ORGANIC CARBON AND NITROGEN IN ANDISOL FOR SIX CROP ROTATIONS WITH DIFFERENT SOIL MANAGEMENT INTENSITY
}

\author{
Pablo Undurraga D. ${ }^{\text {* }}$, Erick Zagal V. ${ }^{2}$, Gloria Sepúlveda W. ${ }^{1}$, and Natalia Valderrama V. ${ }^{3}$
}

\begin{abstract}
Soil organic matter $(\mathrm{OM})$ content is a quality indicator, but is an inadequate indicator in the short-term because these changes take place slowly, so dissolved organic components have emerged as an alternative. In volcanic soil subjected to different crop rotations with distinct land use intensity, dissolved organic C and N (DOC and DON) were determined as well as their relationship with total $\mathrm{C}$ and $\mathrm{N}$ contents in the soil, considering the effects of crop rotation, fertilization level, and soil depth. In humid samples of Humic Haploxerands collected at four depths up to $40 \mathrm{~cm}$, DOC and DON contents were determined by extraction with $\mathrm{K}_{2} \mathrm{SO}_{4}$ and filtered. Results indicated interaction between the studied factors, DOC fluctuated between 67.8 and $151.7 \mathrm{mg} \mathrm{kg}^{-1}$ with the highest value with intensive management in rotations that included corn (Zea mays L.) associated with a higher fertilization. DON fluctuated between 4.62 and $37.4 \mathrm{mg} \mathrm{kg}^{-1}$ with the highest value in non-intensive rotations that included prairie. With respect to total $\mathrm{C}$, DOC reached $0.40 \%$ with intensive management and the lowest value in non-intensive management. DON showed values between 0.13 and $0.68 \%$ with respect to total $\mathrm{N}$ with intensive and non-intensive management, respectively. Tillage management affected DOC and DON contents depending on the fertilization level and the depth at which it was determined, and were also affected by the crop included in the rotation, thus making these parameters good indicators to evaluate the effects of agronomic management in the short-term.
\end{abstract}

Key words: organic matter, dissolved organic matter, total C, total N, volcanic soil.

\section{INTRODUCTION}

Dissolved organic matter (DOM) is present in the soil solution and interacts with the colloids and clays since it can be absorbed and is also a component that leaches. It is made up of plant litter such as microflora, root, and hydrolysis drippings of soil insoluble organic matter $(\mathrm{OM})$. Its origin and function are only partially understood (Neff and Asner, 2001) and its presence has been detected in the water of many ecosystems. Fluxes of DOM are lower than the flux of $\mathrm{C}$ associated with the primary productivity of soils. For this reason, the flux of dissolved organic $\mathrm{C}$ (DOC) is not generally considered as important in the global balance of $\mathrm{C}$ in the ecosystem (Neff and Asner, 2001). DOM shows distinct degrees of mobility and susceptibility to degradation that depend on soil type and absorption capacity due to the types of charges present (Silveira, 2005).

\footnotetext{
'Instituto de Investigaciones Agropecuarias INIA, Casilla 246, Chillán, Chile. *Corresponding author (pundurra@inia.cl).

${ }^{2}$ Universidad de Concepción, Facultad de Agronomía. Av. Vicente Méndez 595, Chillán, Chile.

${ }^{3}$ Universidad de Concepción, Facultad de Ingeniería Agrícola. Av. Vicente Méndez 595, Chillán, Chile.

Received: 07 April 2008.

Accepted: 18 December 2008.
}

DOM can significantly contribute to the nutritional cycles of the soil and could be a substrate for microbial growth which at the same time contributes in its production (Smolander and Kitunen, 2002). DOC and dissolved organic $\mathrm{N}(\mathrm{DON})$ are transformed into an important part of the $\mathrm{C}$ and $\mathrm{N}$ cycle, respectively (Michalzik et al., 2001). According to Neff and Asner (2001), DOC fluxes through the soil are a significant source of $\mathrm{C}$ for microbial activity and represent an important potential loss of this element. DOC has been used in recent research as part of the labile fraction of $\mathrm{OM}$ and as a soil quality indicator (Haynes, 2005). Studies about DOC flux, its dynamics, and microbial activity indicate that virtually all soils have the capacity to stabilize DOC, thus contributing to the balance of C. It is because of this that the soil physical factors are, in a way, responsible for its decrease toward inferior horizons (Haynes, 2005). There is also strong evidence that microbial activity contributes to DOC concentration (Michalzik et al., 2001; Haynes, 2005); however, more information is needed to define its role as a substrate or subproduct of microbial transformation.

Soil quality is mainly determined by OM content which is affected by tillage conditions in its contents and fractions due to crop management (Haynes, 2005). This is how the dissolved labile fraction considered within 
DOC and DON are two components that can be a good indicator of soil biological activity and its fertility, thus allowing evaluating its quality (Neff and Asner, 2001).

Christou et al. (2005) studied DON in soils with different agronomic management, concluding that it is found in non-negligible quantities in intensive agricultural systems with a good quality of residues and high microbial activity. They also indicated that DON represents a significant fraction of total $\mathrm{N}$ dissolved in the soil which is regulated by agricultural activity.

DOC provides an important source of $\mathrm{C}$ for microbial growth which is introduced in the water system as metabolic forms, including carbohydrates, sugars, and amino acids that constitute only a fraction of total DOC (Neff and Asner, 2001). DOC is defined as organic molecules of varying sizes with a diameter of 0.20 to $0.45 \mu \mathrm{m}$, and can be classified as three types of DOM. DOM I is present in soil microaggregates and is not easily biodegradable since it participates in the formation of aggregates and contributes in improving this soil characteristic (Silveira, 2005); however, it can be degraded by microorganisms due to soil alteration. DOM II and III are part of the meso- and macroaggregates, respectively and are easily degradable because of microorganism action. This aspect is a factor relating DOC with soil quality since it participates in its micro structure. DOC is one of the most active reserves in the $\mathrm{C}$ organic cycle and its environmental importance lies in the transport of nutrients such as $\mathrm{N}, \mathrm{P}$, and $\mathrm{S}$, as well as heavy metals and organic contaminants given that they show electrical charges (Jimenez and Lal, 2006).

DON is produced in the soil by microbial activity and vegetation and can be leached to rivers or underground water (Neff and Asner, 2001). It moves toward inferior horizons and there are mechanisms preventing this while others favor it. The magnitude of the flux depends on DON concentration and precipitation level that determine movement within the profile (Silveira, 2005). The way DON appears goes from simple compounds rapidly used by plants and microorganisms to polyphenols or tannins with difficult metabolization (Smolander and Kitunen, 2002). In the last few years, the study of dissolved organic $\mathrm{N}$ forms has become more important, especially in natural ecosystems since inorganic forms and $\mathrm{N}-\mathrm{NO}_{3}$ leaching processes had been previously studied (Perakis and Hedin, 2001; Ghani et al., 2007). Furthermore, DON is considered as important in $\mathrm{N}$ economy in prairie and crop productive systems. The environmental significance of DON as an agent able to retain $\mathrm{N}$ in superficial horizons by absorption depends on its biodegradability since its compounds are known to be easily degradable and others make up the recalcitrant $\mathrm{N}$ pool in the soil.

DOC and DON in soils can be measured through extracts with saline solutions or by extraction of water or solution from the soil by centrifuge (Perakis and Hedin, 2001; Jones and Willett, 2006; Ghani et al., 2007). Normally greater quantities are found when extractions are carried out with saline solutions such as $\mathrm{K}_{2} \mathrm{SO}_{4}$ or $\mathrm{KCl}$ than when extractions are done with distilled water. This is because the DOC and DON components have electrical charges that have the capacity to generate exchange and absorption with soil clays and colloids (Jones and Willett, 2006; Ghani et al., 2007). In the case of DOC and DON quantification in soils, the values obtained are more stable when saline solutions are used for extraction than with distilled water where measured values are erratic and variable (Jones and Willett, 2006).

This study characterized DOC and DON concentrations in soils with different agronomic management. Measuring these two parameters can indicate which applied soil management methods will contribute to these dissolved fractions and quantify the differences that occur. In this way, they can be used as biological indicators of change in the conservation or formation of OM in the soil and their influence on soil quality.

The objective was to determine the effect of agronomic management and crop rotation with distinct intensity in soil use management of DOC and DON contents, in volcanic soil subjected to six crop rotations with two fertilization levels, and relate them to total $\mathrm{C}$ and $\mathrm{N}$ contents and the DOC/DON ratio at four depths.

\section{MATERIALS AND METHODS}

\section{Site description and experimental design}

The study took place in the Santa Rosa experimental field $\left(36^{\circ} 31^{\prime} \mathrm{S}, 71^{\circ} 54^{\prime} \mathrm{W}\right)$ of the Instituto de Investigaciones Agropecuarias INIA, Chillán, Chile. The soil belongs to an Arrayan series (medial, amorphic thermic, Humic Haploxerands), originating from volcanic ash deposited on gravel of alluvial origin (Stolpe, 2006). It shows a loamy texture with contents of 47.5 to $50.2 \%$ sand, 36.8 to $38.6 \%$ lime, and 11.4 to $14.5 \%$ clay, apparent density fluctuates between 1.19 and $1.22 \mathrm{Mg} \mathrm{m}^{-3}$. Soil chemical properties for the first 0 to $20 \mathrm{~cm}$ are shown in Table 1 for the high fertilization level. The climate is Mediterranean with high temperatures during the summer months and scarce precipitation below evaporation, which generates a water deficit for crops and prairies that must be irrigated. Winter has abundant rainfall and low temperatures (Figure 1). This affects the biological dynamics of the soil due to high temperatures and lack of humidity in summer and low temperatures and excess humidity in winter.

The experimental design applied to the treatments corresponded to randomized complete blocks with a split-split-plot arrangement where the principal treatment 
Table 1. Soil chemistry properties for each rotation (main plot) $0-20 \mathrm{~cm}$ with $100 \%$ fertilization (split-plot).

\begin{tabular}{lrrrrrr}
\hline Property & \multicolumn{1}{c}{ Rot 1 } & \multicolumn{1}{c}{ Rot 2 } & \multicolumn{1}{c}{ Rot 3 } & \multicolumn{1}{c}{ Rot 4 } & \multicolumn{1}{c}{ Rot 5 } & \multicolumn{1}{c}{ Rot 6 } \\
\hline Water pH 1:2.5 & $6.36 \pm 0.12$ & $6.59 \pm 0.09$ & $5.47 \pm 0.13$ & $5.80 \pm 0.09$ & $6.28 \pm 0.12$ & $5.94 \pm 0.04$ \\
Organic matter, \% & $8.83 \pm 0.66$ & $8.87 \pm 0.44$ & $9.69 \pm 0.68$ & $9.43 \pm 0.86$ & $9.76 \pm 0.33$ & $10.40 \pm 0.63$ \\
N mineral, mg kg-1 & $19.00 \pm 3.37$ & $12.80 \pm 2.50$ & $16.50 \pm 1.00$ & $14.30 \pm 2.22$ & $18.50 \pm 2.52$ & $20.50 \pm 4.43$ \\
P-Olsen, mg kg-1 & $24.50 \pm 9.35$ & $21.00 \pm 2.23$ & $11.00 \pm 3.49$ & $14.10 \pm 3.38$ & $9.80 \pm 1.76$ & $17.00 \pm 1.96$ \\
Ca exchange, cmol kg-1 & $8.06 \pm 1.68$ & $8.26 \pm 1.26$ & $2.67 \pm 0.74$ & $3.36 \pm 1.04$ & $6.97 \pm 0.42$ & $5.22 \pm 1.21$ \\
Mg exchange, cmol kg-1 & $0.29 \pm 0.10$ & $0.52 \pm 0.13$ & $0.17 \pm 0.04$ & $0.29 \pm 0.10$ & $0.41 \pm 0.07$ & $0.59 \pm 0.12$ \\
K exchange, cmol kg-1 & $0.15 \pm 0.03$ & $0.26 \pm 0.09$ & $0.15 \pm 0.02$ & $0.38 \pm 0.09$ & $0.12 \pm 0.02$ & $0.18 \pm 0.05$ \\
Na exchange, cmol kg-1 & $0.24 \pm 0.04$ & $0.25 \pm 0.15$ & $0.15 \pm 0.04$ & $0.14 \pm 0.04$ & $0.14 \pm 0.02$ & $0.20 \pm 0.02$ \\
Al exchange, cmol kg-1 & $0.02 \pm 0.02$ & $0.01 \pm 0.00$ & $0.17 \pm 0.07$ & $0.06 \pm 0.03$ & $0.02 \pm 0.01$ & $0.05 \pm 0.01$ \\
Al saturation, \% & $0.21 \pm 0.17$ & $0.11 \pm 0.01$ & $5.45 \pm 3.00$ & $1.49 \pm 0.63$ & $0.21 \pm 0.14$ & $0.74 \pm 0.19$ \\
Available Zn, mg kg-1 & $0.31 \pm 0.05$ & $0.34 \pm 0.07$ & $0.21 \pm 0.05$ & $0.30 \pm 0.07$ & $0.36 \pm 0.05$ & $0.41 \pm 0.03$ \\
Available Fe, mg kg-1 & $26.00 \pm 2.90$ & $23.70 \pm 3.27$ & $29.90 \pm 5.22$ & $24.00 \pm 1.75$ & $25.90 \pm 3.88$ & $31.90 \pm 2.69$ \\
Available Cu, mg kg-1 & $1.36 \pm 0.10$ & $1.60 \pm 0.12$ & $0.88 \pm 0.08$ & $1.19 \pm 0.03$ & $1.61 \pm 0.11$ & $1.28 \pm 0.00$ \\
Available Mn, mg kg-1 & $5.23 \pm 1.10$ & $5.05 \pm 1.36$ & $6.75 \pm 1.18$ & $3.97 \pm 0.44$ & $5.34 \pm 0.84$ & $9.30 \pm 1.26$ \\
Available B, mg kg-1 & $0.54 \pm 0.18$ & $0.40 \pm 0.05$ & $0.40 \pm 0.11$ & $0.42 \pm 0.04$ & $0.51 \pm 0.07$ & $0.50 \pm 0.10$ \\
Available S, mg kg-1 & $24.70 \pm 3.26$ & $18.90 \pm 0.74$ & $21.20 \pm 2.08$ & $23.60 \pm 3.11$ & $21.30 \pm 4.91$ & $12.40 \pm 2.93$ \\
\hline
\end{tabular}

Rot: Crop rotation, \pm : Standard deviation of four replicates.

or main plot was the succession of crops (six rotations), the sub-treatment corresponded to the fertilization level (100 and 70\%), and the sub-sub-treatment considered sample depth (four depths). The assay was made up of four blocks where the six main plots were randomly distributed, implementing 24 experimental plots of equal dimension with an area of $560 \mathrm{~m}^{2}(40 \times 14 \mathrm{~m})$. The main plot was divided into two subplots of $280 \mathrm{~m}^{2}(40 \times 7 \mathrm{~m})$ where fertilization varied and the sub-sub-treatment was expressed.

The assay, established in 1992, included crop rotations with intensive management (annual crops), semi-intensive management (annual crops and short prairie rotation), and non-intensive management with annual crops for 3 years and prairies for 5 years. Rotations included the following species: sugar beet (Beta vulgaris L. subsp. vulgaris), wheat (Triticum aestivum L.), red clover (Trifolium pratense L.), bean (Phaseolus vulgaris
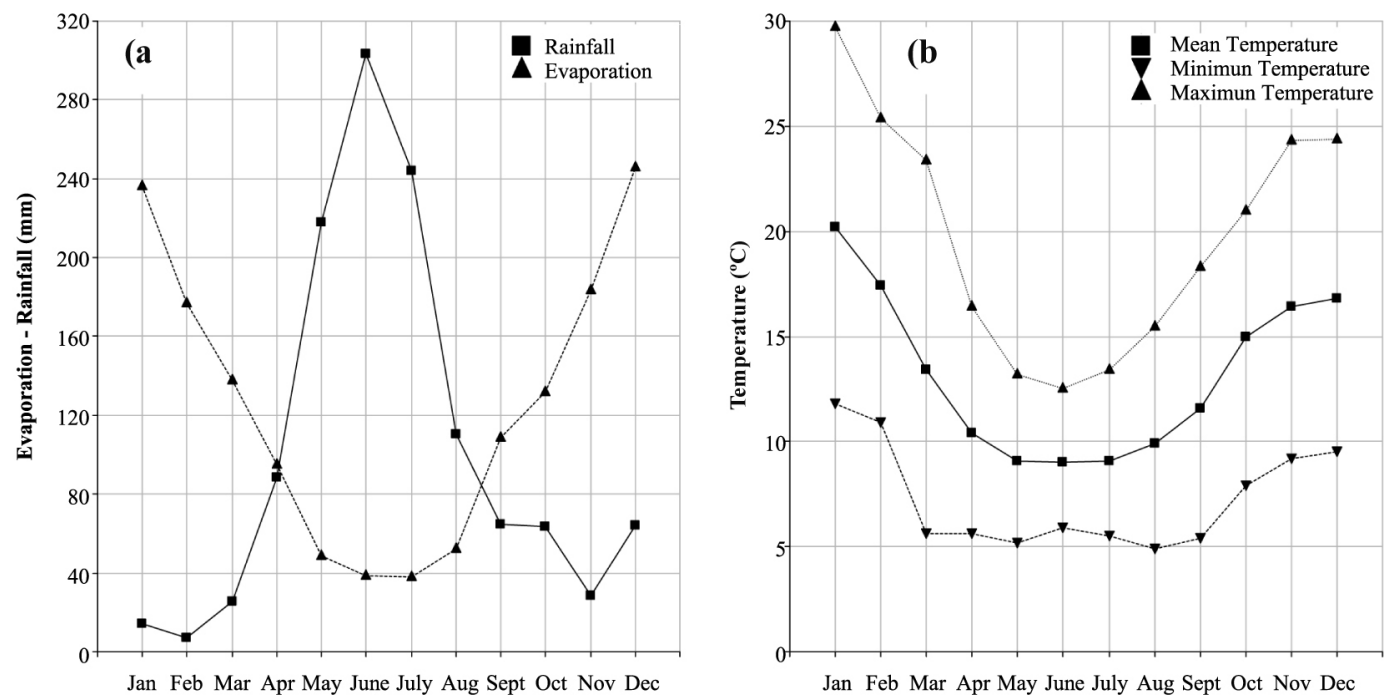

Figure 1. Climatic characteristics of the experimental site, 2004 to 2006 mean. (a) Precipitation and evaporation; (b) mean, minimum, and maximum temperatures (monthly means). 
L.), barley (Hordeum vulgare L.), corn, alfalfa (Medicago sativa L.), white clover (Trifolium repens L.), and English ryegrass (Lolium perenne L.). These were organized in the following way: Rot 1 (semi-intensive), sugar beetwheat-red clover 2 years; Rot 2 (intensive), sugar beetwheat-bean-barley; Rot 3 (semi-intensive), corn-wheatred clover 2 years; Rot 4 (intensive), corn-wheat-beanbarley; Rot 5 (non-intensive), sugar beet-wheat-cornalfalfa, 5 years; Rot 6 (non-intensive), sugar beet-wheatcorn-white clover/English ryegrass, 5 years. Rotations 1 , 2,3 , and 4 were 4 -year cycles and rotations 5 and 6 were 8 -year cycles ( 3 with crops and 5 with prairie). The main plots were divided longitudinally into two subplots that were managed from the start with two N-P-K fertilization levels, high (100\%) and medium (70\%).

\section{Soil sampling and analytical methods}

Sampling to determine DOC and DON contents was carried out in August 2005 by collecting a sample made up of 10 sub-samples in each subplot with a $6 \mathrm{~cm}$ diameter drill bit, and considering four depths up to $40 \mathrm{~cm}$ (0-5, 5-10, 10-20, and 20-40 cm). Samples in intensive and semi-intensive rotations were obtained in the season following the sugar beet crop (Rot 1 and Rot 2) and corn (Rot 3 and Rot 4). Meanwhile, in the non-intensive rotations with prairie, the samples were collected in the third season of alfalfa and white clover/English ryegrass (Rot 5 and Rot 6). A total of 192 compound samples were taken (six rotations, two fertilization levels, four depths, and four blocks). Wet sieving (2 $\mathrm{mm}$ opening) was applied to the samples and a part was stored in bioclimatic chambers at $4{ }^{\circ} \mathrm{C}$, and extractions made to determine DON and DOC.

Samples were also collected to determine fertility indices of the soil, taking 10 sub-samples in each subplot in the cultivable strata $(0-20 \mathrm{~cm})$. Samples were airdried and sieved ( $2 \mathrm{~mm}$ opening). Analyses and methods carried out were the following: $\mathrm{pH}$ measured in water $(1: 2.5 \mathrm{w} / \mathrm{v}) ;$ OM with modified Walkey-Black (Sadzawka et al., 2006) for oxidation with $\mathrm{Na}_{2} \mathrm{Cr}_{2} \mathrm{O}_{7}$ and sulfuric acid; $\mathrm{N}$ mineral $\left(\mathrm{N}-\mathrm{NH}_{4}\right.$ and $\left.\mathrm{N}-\mathrm{NO}_{3}\right)$ was extracted with $\mathrm{KCl} 2 \mathrm{~mol} \mathrm{~L}^{-1}(1: 10 \mathrm{w} / \mathrm{v})$ and determined by colorimetry through the reduction of nitrate to nitrite with $\mathrm{Cd} / \mathrm{Cu}$ and flux injection segmented with an autoanalyzer (Skalar SA 4000, Skalar Analytical B.V., Breda, The Netherlands); available P (P-Olsen) for extraction with $\mathrm{NaHCO}_{3} 0.5$ mol L $\mathrm{L}^{-1}$ and colorimetry of ascorbic acid in a Skalar SA 4000 autoanalyzer; $\mathrm{K}, \mathrm{Na}, \mathrm{Ca}$, and $\mathrm{Mg}$ exchange were extracted with ammonium acetate $1 \mathrm{~mol} \mathrm{~L}^{-1}$ a $\mathrm{pH} 7$ followed by emission spectroscopy and atomic absorption (Unicam 900A, Thermo Scientific Elemental, Waltham,

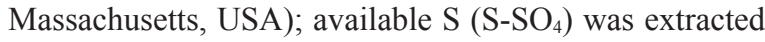
with $0.01 \mathrm{~mol} \mathrm{~L}^{-1} \mathrm{Ca}\left(\mathrm{H}_{2} \mathrm{PO}_{4}\right)_{2}$ and turbidimetry analysis of
$\mathrm{BaSO}_{4} ; \mathrm{Al}$ exchange by extraction with $2 \mathrm{~mol} \mathrm{~L}^{-1} \mathrm{KCl}$ and reading by atomic absorption photometry with acetylenenitrous oxide; available $\mathrm{B}$ was extracted with $0.1 \mathrm{~mol} \mathrm{~L}^{-1}$ $\mathrm{CaCl}_{2}$ and colorimetry. Available $\mathrm{Cu}, \mathrm{Zn}, \mathrm{Fe}, \mathrm{Mn}$ were extracted with EDTA and reading by atomic absorption (Sadzawka et al., 2006).

DON and DOC determinations were carried out in extracts of humid soil with a $0.5 \mathrm{~mol} \mathrm{~L}^{-1} \mathrm{~K}_{2} \mathrm{SO}_{4}$ solution maintaining a humid extraction soil ratio of $1: 5 \mathrm{w} / \mathrm{v}$; it was agitated for $1 \mathrm{~h}$ at $120 \mathrm{rpm}$ and then filtered on Advantec MFS N 5 C paper (Advantec MFS, Dublin, California, USA), equivalent to Whatman 42. Immediately after filtering, $\mathrm{N}$ mineral content $\left(\mathrm{N}^{-\mathrm{NO}_{3}}\right.$ and $\left.\mathrm{N}-\mathrm{NH}_{4}\right)$ was determined by colorimetry by reduction of nitrate to nitrite in $\mathrm{Cd} / \mathrm{Cu}$ and flux injection segmented with Skalar SA 4000 autoanalyzer. Parallel, the humidity content of the soil samples was determined to correct the results of DON and DOC based on dry soil. Extracts were stored in plastic bottles and frozen at $-10{ }^{\circ} \mathrm{C}$, then total dissolved $\mathrm{N}$ and $\mathrm{C}$ were determined. Total dissolved $\mathrm{N}$ was analyzed by autoclave digestion by the persulphate method with the modifications indicated by Doyle et al. (2004). The mixture of reactive persulphate was $50 \mathrm{~g} \mathrm{~K}_{2} \mathrm{~S}_{2} \mathrm{O}_{8} ; 16.8 \mathrm{~g}$ $\mathrm{NaOH} ; 30 \mathrm{~g} \mathrm{H}_{3} \mathrm{BO}_{4}$ per liter, which considers an increase in the concentration of $\mathrm{NaOH} 0.42 \mathrm{~mol} \mathrm{~L}^{-1}$ to increase the $\mathrm{pH}$ of the reagent and avoid persulphate decomposition. Total dissolved $\mathrm{N}$ was determined from the digested extract by flux injection, measuring the nitrate form in a FIAstar 5000 Systems analyzer (FOSS, Hillerod, Denmark). Finally, DON was calculated as the difference between total dissolved $\mathrm{N}$ and mineral $\mathrm{N}$. A part of the frozen extracts was used to determine total dissolved $\mathrm{C}$ by combustion at $675^{\circ} \mathrm{C}$ in an analyzer (model TOC-V CPN, Shimadzu Corporation, Kyoto, Japan). A calibration curve of potassium biftalate of 0 to $50 \mathrm{mg} \mathrm{kg}^{-1} \mathrm{C}$ in the solution was applied. Since the soil in the experiment showed $\mathrm{pH}$ values less than 7 , no inorganic $\mathrm{C}$ was found in the extracts; therefore, DOC corresponded to the determined total dissolved $\mathrm{C}$.

A part of the soil samples used to measure DOC and DON was air-dried and sieved (2 $\mathrm{mm}$ opening) to determine total $\mathrm{C}$ and $\mathrm{N}$ by combustion at $1150{ }^{\circ} \mathrm{C}$ with elemental analyzer (Vario MAX CNS, Elementar Analysensysteme GmbH, Hanau, Germany). This value expressed the relative contents of DOC and DON with respect to the soil totals.

\section{Statistical methodology}

Statistical analysis was carried out in an experimental design of split-split-plots in blocks. The data obtained were processed with the SAS program (SAS Institute, 1999), the General Linear Model (GLM) procedure for analysis of variance (ANOVA), and Tukey test to compare 
means of significant values $(\mathrm{P} \leq 0.05)$. The lineal model associated with the design of subdivided plots was:

$$
\begin{gathered}
Y_{i j k}=\mu+\alpha_{i}+\beta_{j}+\delta_{k}+\pi_{i}+\varrho_{i l}+\lambda_{j i l}+(\alpha \beta)_{i j}+(\alpha \delta)_{i k}+(\beta \delta)_{i k}+(\alpha \beta \delta)_{j k}+\varepsilon_{i j k} \\
i=1,2,3,4,5,6 ; j=1,2 ; k=1,2,3,4 ; l=1,2,3,4
\end{gathered}
$$

where $\mu$ is the general mean, $\alpha_{i}$ mean effect of $i^{\text {th }}$ level of rotation treatment (main plot), $\pi_{l}$ effect of $l^{\text {th }}$ block, $\varrho_{i l}$ random error of the main plot, $\beta_{j}$ mean effect of $j^{\text {th }}$ fertilization level (split-plot), $\alpha \beta$ corresponds to the interaction between rotation and fertilization treatments $\lambda_{i j l}$ random error of the subplot, $\delta_{k}$ mean effect of $k^{\text {th }}$ depth (split-split-plot), $\alpha \delta$ corresponds to the interaction of rotation treatments and depth, $\beta \delta$ interaction of fertilization treatments and depth, $\alpha \beta \delta$ interaction of the three factors, and $\varepsilon$ corresponds to random error of the split-split-plot.

\section{RESULTS AND DISCUSSION}

\section{Effect of crop rotation and fertilization level on DOC and DON content}

There was no direct response to the main treatment or rotation and DOC was affected by the fertilization level and depth of the soil sample (Figure 2). Statistical analysis shows that there was interaction between the evaluated factors (Table 2), just like for DON. DOC contents found in the $100 \%$ fertilization sub-treatment fluctuated between 67.8 and $151.7 \mathrm{mg} \mathrm{kg}^{-1}$ in rotation 1 with a semi-intensive crop and in rotation 4 with an intensive crop at a depth of 0 to $5 \mathrm{~cm}$, respectively (Figure 2). The highest values were obtained in rotations 3 and 4 which included corn as the initial crop of the rotation, and showed lower $\mathrm{pH}$ values, 5.47 and 5.80 respectively, differing from other treatments with considerably higher $\mathrm{pH}$ (Table 1). In general, DOC contents were higher in the $100 \%$ fertilization sub-treatment than the $70 \%$ fertilization subtreatment, distinct values were found in the behavior of each rotation and depth, and tendencies with respect to depth of the studied strata. Rotations 1, 2, and 5 which considered semi-intensive, intensive, and non-intensive management, respectively, had lower contents in the surface and increased in depth for the $100 \%$ fertilization treatment. In contrast, rotations 3, 4, and 6 showed behavior contrary to the previously mentioned rotations with higher DOC contents in the surface and decreasing contents toward the deepest strata (Figure 2). Intensity in soil management of each rotation is not apparently the only factor that determines DOC contents. Increases in DOC with depth could be related to the root development pattern of the crops included in the rotations, especially sugar beet.

In the case of $70 \%$ fertilization, the response of the rotation and depth factors have distinct behaviors without showing great differences in values when depth is changed for rotations $1,2,4$, and 5, showing differences in rotations 3 and 6 (Figure 2), but less than in 100\% fertilization. DOC contents fluctuated between 72.1 and $131.9 \mathrm{mg} \mathrm{kg}^{-1}$ in rotation 1 with 20 to $40 \mathrm{~cm}$ depth and rotation 3 with 5 to $10 \mathrm{~cm}$, respectively (Figure 2). Thus, a distinct behavior was demonstrated than with $100 \%$ fertilization, since the lowest value was obtained in the superficial strata of the same rotation and the highest value in rotation 3. Rotations 1 and 2 included sugar beet as their initial crop which considered applications of calcareous lime each year that corresponded to this crop in quantities of 2 to $3 \mathrm{t} \mathrm{ha}^{-1}$ of calcium carbonate. The difference in management of rotations 3 and 4 that included corn is that liming was not considered and $300 \mathrm{~kg} \mathrm{ha}^{-1}$ of fertilization with $\mathrm{N}$ as urea was applied in the $100 \%$ fertilization subtreatment which led to a decrease in $\mathrm{pH}$ (Table 1).
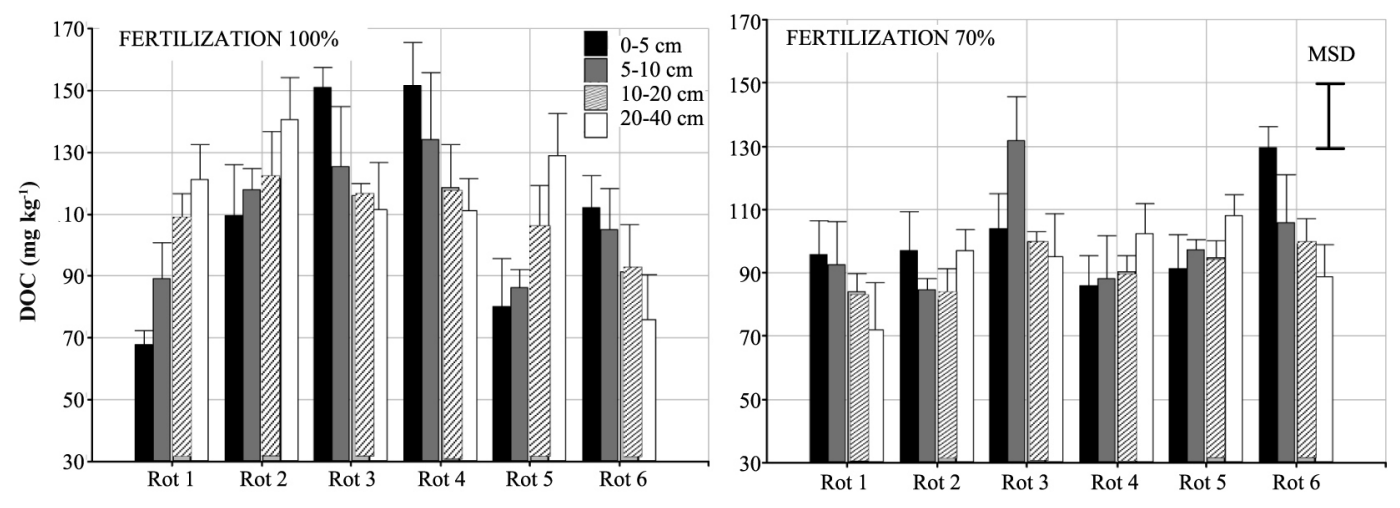

Mininum significant difference (MSD) according to Tukey test $(\mathrm{P} \leq 0.05)$ for $\mathrm{DOC}=21.5 \mathrm{mg} \mathrm{kg} \mathrm{g}^{-1}$.

Figure 2. Dissolved organic carbon (DOC) contents for each crop rotation with two fertilization levels (100 and $70 \%$ ) for different soil depths. 
Table 2. Variation source, degrees of freedom, and probability from analysis of variance for seven studied variables.

\begin{tabular}{|c|c|c|c|c|c|c|c|c|}
\hline \multirow[b]{2}{*}{ Source } & & $\underset{\mathbf{g ~ k g}^{-1}}{\mathbf{T N}}$ & $\underset{\mathrm{g} \mathrm{kg}^{-1}}{\mathbf{T C}}$ & $\begin{array}{c}\text { DOC } \\
\text { mg kg-1 }^{-1}\end{array}$ & $\underset{\text { mg kg-1 }^{-1}}{\text { DON }}$ & DOC/DON & DON/TN & DOC/TC \\
\hline & & $\mathbf{P}>\mathbf{F}$ & $\mathbf{P}>\mathbf{F}$ & $\mathbf{P}>\mathbf{F}$ & $\mathbf{P}>\mathbf{F}$ & & & \\
\hline Block & 3 & 0.0313 & 0.0033 & 0.5296 & 0.0061 & 0.0005 & 0.1005 & 0.1005 \\
\hline Rotation (CR) & 5 & $0.0056^{* *}$ & $0.0141 *$ & $0.0002 * * *$ & $<0.0001 * * *$ & $0.0002 * * *$ & $0.0048 * * *$ & $<0.0001 * * *$ \\
\hline Error a & 15 & 0.0053 & 0.0050 & 0.0111 & 0.0158 & 0.4462 & 0.0019 & 0.0006 \\
\hline Fertilization $(\mathrm{F})$ & 1 & $0.0101 *$ & $0.0998 \mathrm{~ns}$ & $<0.0001 * * *$ & $0.0021 * *$ & $0.1087 \mathrm{~ns}$ & $<0.0001 * * *$ & $0.0062 * *$ \\
\hline $\mathrm{CR} \times \mathrm{F}$ & 5 & $0.1387 \mathrm{~ns}$ & $0.1207 \mathrm{~ns}$ & $<0.0001 * * *$ & $<0.0001 * * *$ & $0.0127^{*}$ & $<0.0001 * * *$ & $<0.0001 * * *$ \\
\hline Error b & 18 & 0.4928 & 0.3548 & 0.4252 & 0.3017 & 0.4891 & 0.1616 & 0.2420 \\
\hline Depth (D) & 3 & $<0.0001 * * *$ & $<0.0001 * * *$ & $0.1061 \mathrm{~ns}$ & $<0.0001 * * *$ & $<0.0001 * * *$ & $<0.0001 * * *$ & $<0.0001 * * *$ \\
\hline$C R \times D$ & 15 & $<0.0001 * * *$ & $<0.0001 * * *$ & $<0.0001 * * *$ & $<0.0001 * * *$ & $<0.0001 * * *$ & $<0.0001 * * *$ & $<0.0001 * * *$ \\
\hline $\mathrm{F} \times \mathrm{D}$ & 3 & $0.4524 \mathrm{~ns}$ & $0.3613 \mathrm{~ns}$ & $0.0290 *$ & $0.3626 \mathrm{~ns}$ & $0.9552 \mathrm{~ns}$ & $0.0048 * *$ & $0.2193 \mathrm{~ns}$ \\
\hline CR $x F \times D$ & 15 & $0.6252 \mathrm{~ns}$ & $0.2595 \mathrm{~ns}$ & $<0.0001 * * *$ & $<0.0001 * * *$ & $0.2463 \mathrm{~ns}$ & $<0.0001 * * *$ & $<0.0001 * * *$ \\
\hline Error c & 108 & & & & & & & \\
\hline Coeff. variation & & 8.896 & 6.316 & 10.432 & 20.883 & 29.094 & 20.632 & 13.130 \\
\hline
\end{tabular}

$*, * *, * * *$ : indicate significant difference at 5,1 , and $0.1 \%$ respectively.

DF: Degrees of freedom. P > F: Probability greater than critical value of F; ns: not significant; TN: total N; TC: total C; DOC: dissolved organic C; DON: dissolved organic N; DON/TN ratio of DON with respect to total $\mathrm{N}$ for 100; DOC/TC ratio of dissolved organic C with respect to total C for 100 .

Management factors, such as fertilization, greatly influenced DOC contents found, which results in the crop rotation not having an effect in and of itself, but that they are affected by factors that modify soil chemical properties and fertility, especially in Andisols where this study was carried out, those that show variable charge dependent on pH. This coincides with Kemmitt et al. (2006), who determined the liming effect in two long-term assays in southeastern England and found values between 30 and $140 \mathrm{mg} \mathrm{kg}^{-1}$ of DOC that they significantly correlated with soil $\mathrm{pH}$, obtaining the highest values of DOC associated with the lowest $\mathrm{pH}$ in both assays. Similar conditions of DOC behavior, which show increases in contents when soil $\mathrm{pH}$ decreases, have also been reported in English soils (Cookson et al., 2007). In contrast, Filep et al. (2003) found increases in DOC content when applying calcium carbonate in an Arenosol in Kisvarda, Hungary, in an experiment with pots.

DON contents fluctuated between 4.6 and $37.4 \mathrm{mg}$ $\mathrm{kg}^{-1}$ in rotation 5 of the $70 \%$ fertilization sub-treatment in the 20 to $40 \mathrm{~cm}$ and 0 to $5 \mathrm{~cm}$ strata depths, respectively. This rotation corresponded to non-intensive management that included a sequence of crops and prairies with sugar beet, wheat, corn, and alfalfa for 5 years. Likewise, it can be seen that the highest contents of DON were obtained in the first strata for rotations that included prairie (rotations 5 and 6), for both fertilization sub-treatments (70 and $100 \%$ ) (Figure 3). The $70 \%$ fertilization sub-treatment did not show any significant differences between intensive and semi-intensive rotations, nor among the distinct depths under study (Figure 3). Meanwhile, in the $100 \%$ fertilization treatment, significant differences were observed in these rotations, for example, obtaining intermediate values of DON in rotation 3 with semiintensive management that included corn where we found values of 13.8 to $15.9 \mathrm{mg} \mathrm{kg}^{-1}$ for the first three strata that made up the topsoil 0 to $20 \mathrm{~cm}$. Values found contrasted with those obtained by Christou et al. (2005), who used extraction with water to determine DON in different agricultural ecosystems in Wales, UK. These authors found greater quantities in citrus intensive orchards, followed by horticultural crops and forest plantations. They reported similar quantities for soils with crops and prairies.

Higher values in soils that include prairie in the rotation concur with other biological parameters found by Zagal and Córdova (2005), in the same assay where they obtained values of $95 \%$ biomass $\mathrm{C}$ (rotations 5 and 6) with respect to intensive rotations (rotations 2 and 4), and $52 \%$ higher with respect to semi-intensive rotations (rotations 1 and 3). Likewise, for non-intensive rotations, they obtained values $166 \%$ higher than the semi-intensive rotations for biomass $\mathrm{N}$. In another study, Zagal et al. (2002) obtained much higher values of mineralized C and $\mathrm{N}$ in rotations 5 and 6 of non-intensive management with respect to intensive and semi-intensive rotations. This also concurs with some physical parameters such as the size of microaggregates and saturated hydraulic 

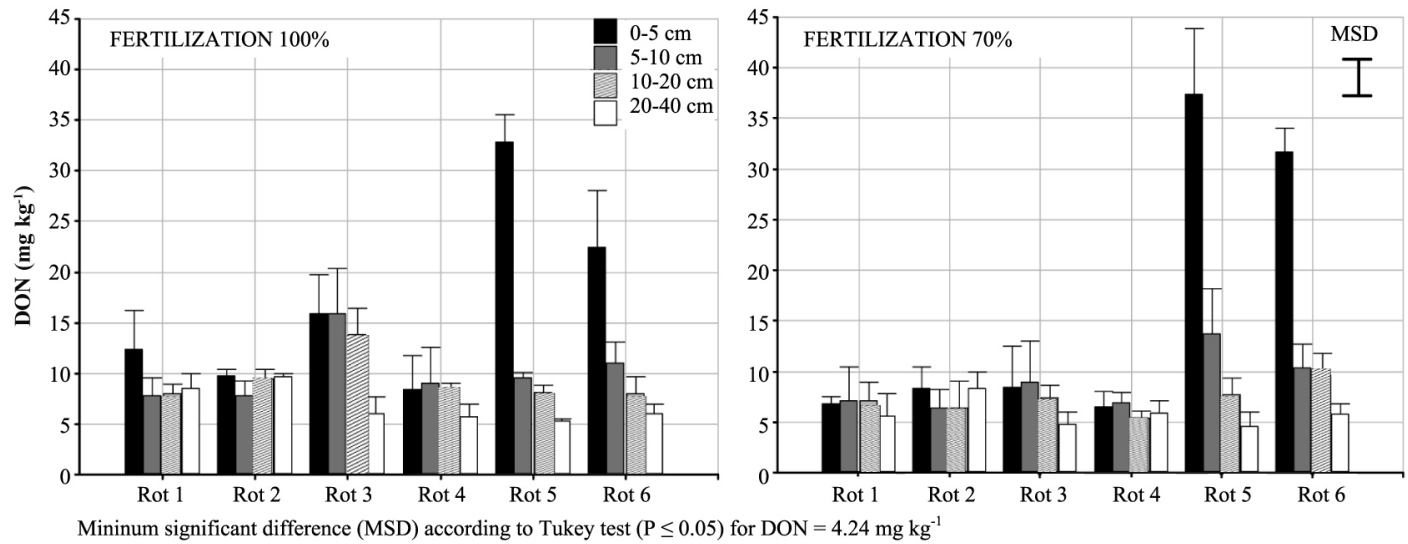

Figure 3. Dissolved organic nitrogen (DON) contents for each crop rotation with two fertilization levels (100 y $70 \%$ ) for different soil depths.

conductivity reported by Sandoval et al. (2007a; 2007b) in the superficial strata. In general, literature is scarce about the quantification of DON in agricultural soils. DON values found in this study were similar to those presented by Filep et al. (2003) in an Arenosol, but with a broader range than that reported for Alfisols in the UK with 6 to $23 \mathrm{mg} \mathrm{kg}^{-1}$ (Kemmitt et al., 2005; 2006; Cookson et al., 2007). Just like in this study, the highest values were found in soils managed with prairies in the first 0 to $5 \mathrm{~cm}$ depth. These authors also reported an unclear relationship between DON and soil $\mathrm{pH}$.

DOC and DON contents respond to and interact with different factors such as soil management, crop rotation, initial crop in the rotation, and associated fertilization. According to this, response is variable and depends on soil chemical factors that are affected by fertilization, liming, and the depth at which it is determined, suggesting the importance of estimating diverse parameters in the evaluation of soil dynamics and quality. This was very relevant in the determination of DOC contents, but less evident for DON values where non-intensive soil management produced higher contents.

\section{Relationship between dissolved organic carbon and nitrogen (DOC/DON)}

The relationship between the two most important components of DOM has a behavior which is different to that shown by DOC and DON alone. The relationship between DOC and DON showed significant differences for rotation (main treatment) and depth (sub-sub-treatment), unlike the fertilization level. Values of the DOC/DON ratio showed a maximum of 24.8 and a minimum of 2.5 (Table 3) found in rotation 5 in the 20 to $40 \mathrm{~cm}$ and 0 to $5 \mathrm{~cm}$ strata, respectively. However, it can be seen that in the first two strata, 0 to 5 and 5 to $10 \mathrm{~cm}$ for rotations including prairie for 5 years (rotations 5 and 6 ) had the lowest DOC/DON values (Table 3). This coincided with a greater activity of the microbial biomass (biomass size and respiration) found for this same experiment by Zagal et al. (2002) and Zagal and Córdova (2005), parameters that were equally associated to a greater or lesser intensity of soil use. DOM constituted a substrate for soil microorganism activity (Haynes, 2005; Silveira, 2005). In the 10 to 20 and 20 to $40 \mathrm{~cm}$ strata, the behavior pattern changed. This could indicate that DOC and DON are influenced by crop type and root development pattern, which in the case for some forage species show the highest concentration in the first $10 \mathrm{~cm}$ of soil. This is also valid for rotation 5 including alfalfa, since soil management and low fertility (Table 1) showed a population decrease increasing white clover. This situation would indicate that the root drippings contribute to increasing DON in this type of prairie.

It has been reported that the $\mathrm{DOC} / \mathrm{DON}$ ratio quantifies losses of DOM in hydrological studies where values are

Table 3. Relationship between dissolved organic carbon (DOC) and dissolved organic nitrogen (DON) in six crop rotations and four soil depths.

\begin{tabular}{lrrrc}
\hline & \multicolumn{4}{c}{ Depth $(\mathbf{c m})$} \\
\cline { 2 - 5 } Rotation & $\mathbf{0 - 5}$ & $\mathbf{5 - 1 0}$ & $\mathbf{1 0 - 2 0}$ & $\mathbf{2 0 - 4 0}$ \\
\hline Rot 1 & 10.2 & 13.6 & 13.1 & 15.2 \\
Rot 2 & 11.8 & 14.7 & 13.6 & 13.2 \\
Rot 3 & 12.4 & 12.7 & 11.2 & 20.1 \\
Rot 4 & 17.3 & 14.8 & 15.9 & 19.2 \\
Rot 5 & 2.5 & 8.4 & 12.9 & 24.8 \\
Rot 6 & 4.7 & 10.2 & 11.3 & 14.3 \\
\hline
\end{tabular}

Rot: Crop rotation.

Minimum significant difference (MSD) according to Tukey test $(\mathrm{P} \leq 0.05)$ for $\mathrm{DOC} / \mathrm{DON}=5.40$. 
distinct depending on soil type. This is how, for Andisols of southern Chile and Argentina, in forest ecosystems values were $29 \pm 5.7$ compared to soil parent materials of another origin with values of $73 \pm 6.2$ (Perakis and Hedin, 2007). Likewise, DON and DOC contents in soil solutions of volcanic origin were lower than in other soil types. Ghani et al. (2007) found values from 5.9 to 9.0 for the DOC/DON ratio in Andisols and Inceptisols in New Zealand with prairies for dairy cows and sheep. These are within the values obtained in this study. However, they obtained higher DOC and DON values with ranges from 73 to $718 \mathrm{mg} \mathrm{kg}^{-1}$ for the first and 13 to $93 \mathrm{mg} \mathrm{kg}^{-1}$ for the second with a $0.5 \mathrm{M} \mathrm{K}_{2} \mathrm{SO}_{4}$ extraction solution.

The highest DON contents in the ecosystems can be related to the indications by Perakis and Hedin (2001) and Davidson et al. (2003) who set out abiotic mechanisms for DON production through a loss of nitrate by reduction and later conversion to DON. For this to occur, three conditions must exist: presence of available $\mathrm{Fe}$ and $\mathrm{Mn}$ minerals in the soil; microsites with anaerobic conditions due to a high microbial and/or root respiration; and finally, an abundant DOC content that can react with $\mathrm{NO}_{3}^{-}$to convert it into DON. These three conditions can be found in the first strata of soils with prairies since Andisols show
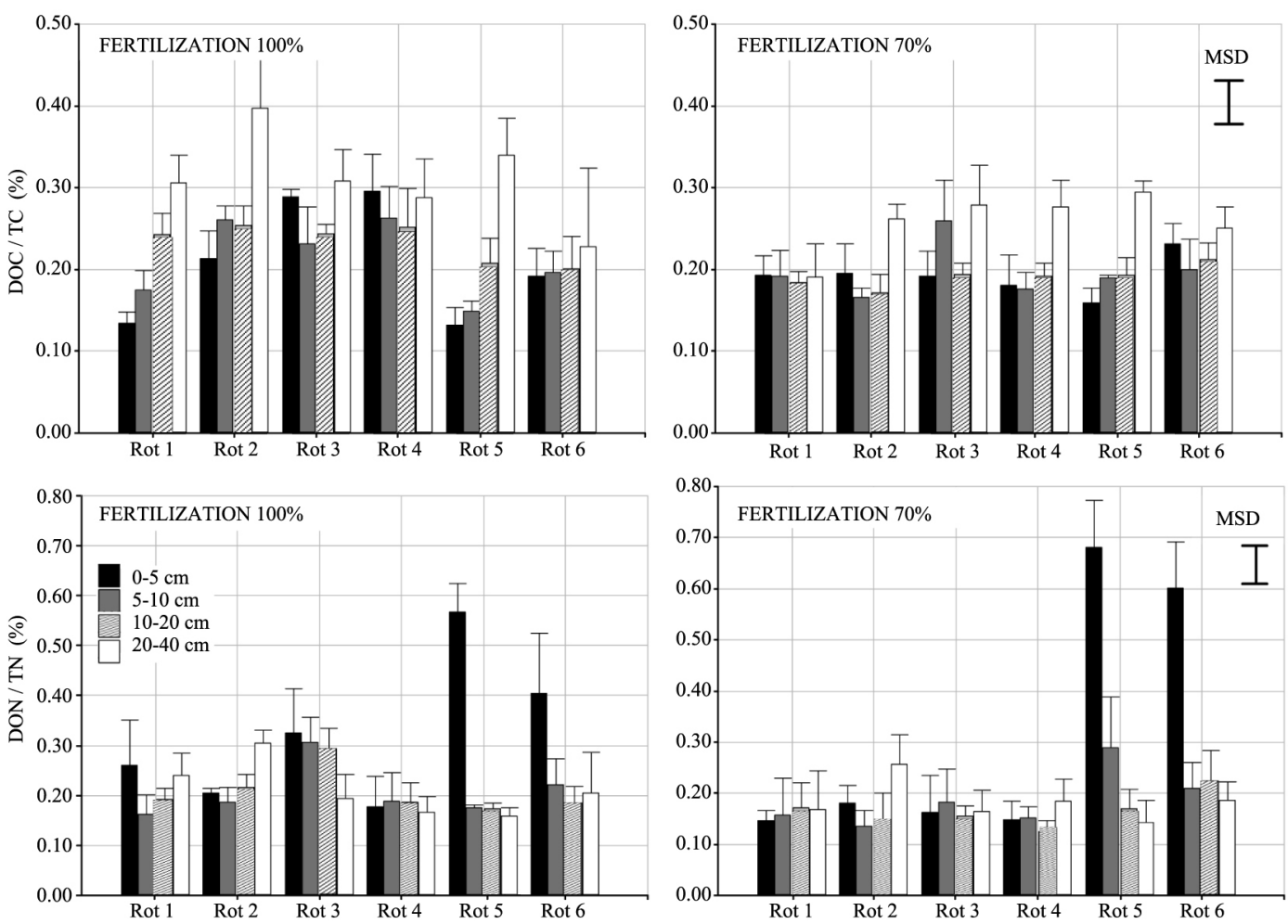

Mininum significant difference (MSD) according to Tukey test $(\mathrm{P} \leq 0.05)$ for $\mathrm{DOC} / \mathrm{TC}=0.06$ and $\mathrm{DON} / \mathrm{TN}=0.09$

Figure 4. Dissolved organic carbon and nitrogen content (DOC and DON) expressed as a percentage of total C and $\mathbf{N}$ for crop rotation, fertilization levels, and soil depth. 
for the $100 \%$ fertilization. The lowest content was found in the same treatment and depth with $0.16 \%$ (rotation $5 ; 0-5 \mathrm{~cm}$ ) and the highest value was found in rotation 3 with semi-intensive management at 20 to $40 \mathrm{~cm}$ with $0.28 \%$ (Figure 4). These are lower than those presented by Kemmitt et al. (2006), who found values of up to $0.8 \%$ for DOC with respect to TC in European soils.

DON showed values between 0.13 and $0.68 \%$ with respect to $\mathrm{TN}$ in the $70 \%$ fertilization sub-treatment with the lowest value in rotation 4 at 10 to $20 \mathrm{~cm}$ and the highest in rotation 5 in the superficial strata. The behavior of DON with respect to TN is equal to DON by itself as can be seen when comparing Figure 4 and Figure 3. Intermediate values of 0.16 and $0.57 \%$ are shown for the $100 \%$ fertilization sub-treatment in rotation 5 with non-intensive management in the 20 to $40 \mathrm{~cm}$ and 0 to $5 \mathrm{~cm}$ strata respectively (Figure 4). Values found were higher than those presented in the literature for soluble fractions of $\mathrm{OM}$ estimated between 0.05 and $0.40 \%$ of soil total organic $\mathrm{C}$ and $\mathrm{N}$ (Haynes, 2005). However, it is worth noting that the results found in this study for percent of DON/TN coincide with the tendency of those observed for DON content and DOC/DON ratio on the surface $(0-5 \mathrm{~cm})$. This is an influence of soil management intensity in these parameters. In this way, it was possible to determine higher values of DON (Figure 3 ) and DON/ TN (Figure 4), with significant differences for rotations with non-intensive management (rotations 5 and 6) when comparing them to the most intensive (rotations 2 and 4), and with intermediate values for semi-intensive (rotations 1 and 3).

\section{CONCLUSIONS}

Agronomic soil management with different crop rotations and prairies affects the quantities of DOC and DON produced in the soil and responds differently in accordance with management intensity and the depth at which they are determined. The contents of DOC depend on the initial crop of the rotation and fertilization applied. Rotations that included sugar beet showed lower DOC contents on the surface, this behavior being contrary to the rotations that included corn where high contents were found in the 0 to $5 \mathrm{~cm}$ strata, associated with a lower $\mathrm{pH}$ for high $\mathrm{N}$ fertilization applied to this crop.

DON responds to soil management intensity generating the highest concentration in the first $5 \mathrm{~cm}$ in non-intensive rotations that include prairie for 5 years. The response of DON, DOC/DON, and DON/TN to soil management, at least in the topsoil $(0-5 \mathrm{~cm})$, contrasts with non-intensive and intensive soil management and can be used as good biological indicators of changes in $\mathrm{OM}$, as more sensitive parameters than soil total $\mathrm{C}$ and $\mathrm{N}$.

\section{RESUMEN}

Carbono y nitrógeno orgánicos disueltos en un Andisol sometido a seis rotaciones de cultivos con diferente intensidad en el manejo del suelo. El contenido de materia orgánica $(\mathrm{OM})$ del suelo es un indicador de su calidad, sin embargo los cambios se producen lentamente, no siendo un indicador adecuado en el corto plazo, surgiendo los componentes orgánicos disueltos como una alternativa. En un suelo volcánico sometido a diferentes rotaciones de cultivos con distinta intensidad en el uso de suelo, se determinó el $\mathrm{C}$ y $\mathrm{N}$ orgánicos disueltos (DOC y DON) y su relación con los contenidos de $\mathrm{C}$ y $\mathrm{N}$ totales del suelo, considerando los efectos de la rotación de cultivos, nivel de fertilización y profundidad del suelo. En muestras húmedas de un Humic Haploxerands recolectadas a cuatro profundidades hasta los $40 \mathrm{~cm}$, se determinaron los contenidos de DOC y DON mediante extracción con $\mathrm{K}_{2} \mathrm{SO}_{4}$ y filtrado. Los resultados indicaron interacción entre los factores estudiados, DOC fluctuó entre 67,8 y $151,7 \mathrm{mg} \mathrm{kg}^{-1}$ con el mayor valor bajo manejo intensivo, en rotaciones que incluyeron maíz (Zea mays L.) asociado a mayor fertilización. El DON fluctuó entre 4,62 y 37,4 $\mathrm{mg} \mathrm{kg}^{-1}$ con el mayor valor en rotaciones no intensivas que incluyeron pradera. El DOC con respecto al C total, alcanzó a $0,40 \%$ en manejo intensivo y el menor valor en manejo no-intensivo. El DON presentó valores entre 0,13 y $0,68 \%$ con respecto al $\mathrm{N}$ total, en manejo intensivo y nointensivo, respectivamente. El manejo de labranza afectó los contenidos de DOC y DON dependiendo del nivel de fertilización y de la profundidad a la cual se determinan, siendo afectados por el cultivo incluido en la rotación, haciendo de estos parámetros buenos indicadores para evaluar efectos del manejo agronómico en el corto plazo.

Palabras clave: materia orgánica, materia orgánica disuelta, $\mathrm{C}$ total, $\mathrm{N}$ total, suelo volcánico.

\section{LITERATURE CITED}

Christou, M., E.J. Avramides, J.P. Roberts, and D.L. Jones. 2005. Dissolved organic nitrogen in contrasting agricultural ecosystems. Soil Biol. Biochem. 37:15601563.

Cookson, W.R., M. Osman, P. Marschnerc, D.A. Abaye, I. Clark, D.V. Murphy, et al. 2007. Controls on soil nitrogen cycling and microbial community composition across land use and incubation temperature. Soil Biol. Biochem. 39:744-756.

Davidson, E.A., J. Chorover, and D.B. Dail. 2003. A mechanism of abiotic immobilization of nitrate in forest ecosystems: the ferrous wheel hypothesis. Global Change Biol. 9:228-236. 
Doyle, A., M.N. Weintraub, and J.P. Schimel. 2004. Persulfate digestion and simultaneous colorimetric analysis of carbon and nitrogen in soil extracts. Soil Sci. Soc. Am. J. 68:669-676.

Filep, T., I. Kincses, and P.T. Nagy. 2003. Dissolved organic carbon (DOC) and dissolved organic nitrogen (DON) content of an Arenosol as affected by liming in a pot experiment. Arch. Agron. Soil Sci. 49:111-117.

Ghani, A., M. Dexter, R.A. Carran, and P.W. Theobald. 2007. Dissolved organic nitrogen and carbon in pastoral soils: the New Zealand experience. Eur. J. Soil Sci. 58:832-843.

Haynes, R.J. 2005. Labile organic matter fractions as central components of the quality of agricultural soils: An overview. Adv. Agron. 85:221-268.

Jimenez, J.J., and R. Lal. 2006. Mechanisms of C sequestration in soils of Latin America. Crit. Rev. Plants Sci. 25:337-365.

Jones, D.L., and V.B. Willett. 2006. Experimental evaluation of methods to quantify dissolved organic nitrogen (DON) and dissolved organic carbon (DOC) in soil. Soil Biol. Biochem. 38:991-999.

Kemmitt, S.J., D. Wright, K.W.T. Goulding, and D.L. Jones. 2006. $\mathrm{pH}$ regulation of carbon and nitrogen dynamics in two agricultural soils. Soil Biol. Biochem. 38:898-911.

Kemmitt, S.J., D. Wright, and D.L. Jones. 2005. Soil acidification used as a management strategy to reduce nitrate losses from agricultural land. Soil Biol. Biochem. 37:867-875.

Michalzik, B., K. Kalbitz, J.H. Park, S. Solinger, and E. Matzner. 2001. Fluxes and concentrations of dissolved organic carbon and nitrogen - a synthesis for temperate forests. Biogeochemistry 52:173-205.

Neff, J.C., and G.P. Asner. 2001. Dissolved organic carbon in terrestrial ecosystems: synthesis and a model. Ecosystems 4:29-48.

Perakis, S.S., and L.O. Hedin. 2001. Fluxes and fates of nitrogen in soil of an unpolluted old-growth temperate forest, southern Chile. Ecology 82:2245-2260.
Perakis, S.S., and L.O. Hedin. 2007. State factor relationships of dissolved organic carbon and nitrogen losses from unpolluted temperate forest watersheds. J. Geophys. Res. 112, G02010. doi:10.1029/2006JG000276.

Sadzawka, A, M.A. Carrasco, R. Grez, M.L. Mora, H. Flores, y A. Neaman. 2006. Métodos de análisis de suelos recomendados para los suelos de Chile. Revisión 2006. Serie Actas $\mathrm{N}^{\circ} 34$. Instituto de Investigaciones Agropecuarias (INIA), Santiago, Chile.

Sandoval, M., C. Castillo, E. Zagal, N. Stolpe, y P. Undurraga. 2007a. Parámetros hidráulicos determinados en un Andisol bajo diferentes rotaciones culturales después de diez años. R. C. Suelo Nutr. Veg. 7:32-45.

Sandoval, M.A., N.B. Stolpe, E.M. Zagal, and M. Mardones. 2007b. The effect of crop-pasture rotations on the $\mathrm{C}, \mathrm{N}$ and $\mathrm{S}$ contents of soil aggregates and structural stability in a volcanic soil of south-central Chile. Acta Agr. Scand. B-S P 57:255-262.

SAS Institute. 1999. The SAS system product installation. SAS Institute Inc., Cary, North Carolina, USA.

Silveira, M.L.A. 2005. Dissolved organic carbon and bioavailability of $\mathrm{N}$ and $\mathrm{P}$ as indicators of soil quality. Sci. Agric. (Piracicaba, Braz.) 62:502-508.

Smolander, A., and V. Kitunen. 2002. Soil microbial activities and characteristics of dissolved organic $\mathrm{C}$ and $\mathrm{N}$ in relation to tree species. Soil Biol. Biochem. 34:651-660.

Stolpe, N.B. 2006. Descripción de los principales suelos de la VIII Región de Chile. 84 p. Universidad de Concepción, Facultad de Agronomía, Departamento de Suelos y Recursos Naturales, Chillán, Chile.

Zagal, E., y C. Córdova. 2005. Indicadores de calidad de la materia orgánica del suelo en un Andisol cultivado. Agric. Téc. (Chile) 65:186-197.

Zagal, E., N. Rodríguez, I. Vidal, y L. Quezada. 2002. Actividad microbiana en un suelo de origen volcánico bajo distinto manejo agronómico. Agric. Téc. (Chile) 62:297-309. 